\title{
Research
}

Mujahed Shraim, Christian D Mallen and Kate M Dunn

\section{GP consultations for medically unexplained physical symptoms in parents and their children:}

\author{
a systematic review
}

\begin{abstract}
\section{Background}

There is evidence of an association of medically unexplained physical symptoms (MUPS) between parents and children, but it is unclear whether this association is also present for GP consultations.
\end{abstract}

\section{Aim}

To review the literature investigating the association of GP consultations for MUPS between parents and children.

\section{Design of study}

Systematic review.

\section{Method}

Systematic search of MEDLINE ${ }^{\circledR}$, Embase, CINAHL, and PsycINFO databases from their inception to October 2012. Observational studies examining the association of GP consultations for MUPS between parents and children were included.

\section{Results}

Eight studies were included in the review. Three studies found significant associations between GP consultations for multiple MUPS between parents and children. Two studies reported significant associations between irritable bowel syndrome diagnosis in parents and multiple MUPS in children. One study showed no significant associations between multiple MUPS in mothers and functional abdominal pain in children. Two studies investigated the association of non-specific low back pain in parents and children; one study showed a significant association, whereas the other study found no significant association. Formal pooling of the results was not performed owing to a high degree of study heterogeneity.

\section{Conclusion}

This review provides evidence of an association between GP consultations for MUPS in parents and children, although the evidence is limited by some potential biases and study heterogeneity. GPs need to be aware of this association, which has implications for management of children presenting with MUPS. More longitudinal research focusing on all common MUPS in children, which relies on more precise sources of data, is needed to further investigate this association.

\section{Keywords}

children; signs and symptoms; parents; primary health care; review, systematic.

\section{INTRODUCTION}

Non-specific physical symptoms, such as musculoskeletal pain and headache, are widespread in the community and are among the most common reasons for visiting a GP. In the UK, recent research indicates that the annual GP consultation prevalence for musculoskeletal symptoms is $25 \%$ and for headache is about $4.4 \% .^{1,2}$ Many physical complaints remain medically unexplained, owing to lack of obvious cause or pathological changes on physical examination and diagnostic testing. Medically unexplained physical symptoms (MUPS) are defined as physical symptoms that lead the patient to seek health care, and after clinical assessment do not seem to be explained by a clearly defined cause or diagnosis of a defined medical disease.,3

The majority of patients presenting in primary care with MUPS improve within a few weeks, ${ }^{5}$ although about one-quarter of patients experience persistent or recurrent MUPS. ${ }^{6}$ MUPS are also common among children, and persist in a considerable proportion of children.7-9 Recurrent or persistent MUPS among children are associated with excessive utilisation of healthcare services, functional impairment, and negative impact on the quality of life of children and parents. ${ }^{10-12}$ Children with MUPS are also at greater risk of developing other MUPS and psychiatric disorders later in life. $9.13,14$

The causes of MUPS are still poorly understood, but are likely to be multifactorial. Research evidence suggests

M Shraim, MPH, BSc, PhD student; CD Mallen $\mathrm{PhD}$, professor of general practice, director of academic general practice, director of clinical academic training, Arthritis Research UK clinician scientist; KM Dunn, PhD, Wellcome Trust reader in epidemiology, Arthritis Research UK Primary Care Centre, Keele University, Keele.

\section{Address for correspondence}

Kate M Dunn, Arthritis Research UK Primary Care Centre, Primary Care Sciences, Keele University, that MUPS among children may be related to a number of factors, including stressful events related to schooling and social relationships, ${ }^{15,16}$ psychopathology, ${ }^{17,18}$ childhood abuse and neglect, 19,20 pubertal development, ${ }^{21}$ and poor parental health. ${ }^{22,23}$

Several studies have demonstrated that parental health is related to the health of the child, particularly when parents experience MUPS. Parents with MUPS and/ or anxiety or depression are more likely to have children with high GP attendance rates and perceive their children to have symptoms. ${ }^{22}$ Children of mothers with chronic somatisation disorder (MUPS for at least 2 years) are more likely to have health problems and more GP consultations than children of mothers with explained chronic illness or mothers without chronic illness. ${ }^{24}$ Similarly, children of mothers with irritable bowel syndrome (IBS) have more disability days and GP consultations for gastrointestinal (GI) and non-Gl symptoms than children of mothers without IBS. ${ }^{23}$ Some studies have focused on the associations of painful MUPS between parents and children, and reported mixed results. A few studies found no associations for any pain Imusculoskeletal pain, widespread pain, and non-specific low back pain [NLBP]], ${ }^{25}$ functional abdominal pain (FAP), ${ }^{26}$ and $\mathrm{NLBP}^{27}$ between parents and children. Conversely, other studies found significant associations for back pain or headache, ${ }^{28-30}$ and FAP between parents and children. ${ }^{31,32}$

As MUPS are a significant burden in

Staffordshire, ST5 5BG

E-mail: k.m.dunnakeele.ac.uk

Submitted: 2 November 2012; Editor's response: 11 December 2012; final acceptance: 17 December 2012

@British Journal of General Practice

This is the full-length article (published online 29 Apr 2013) of an abridged version published in print. Cite this article as: Br J Gen Pract 2013; DOI: 10.3399/bjgp13X667178 


\section{How this fits in}

There is evidence of an association of medically unexplained physical symptoms (MUPS) between parents and children, but it is unclear whether this translates to similar patterns of GP consultations for MUPS between parents and children. This study found evidence of an association between GP consultations for MUPS in parents and their children. GPs need to be aware of this link, which has implications for the management and prevention of MUPS among children in primary care.

primary care, it is important to know if the association of MUPS between parents and children is also present for GP consultations. It is important to identify and better understand possible associations of GP consultation for MUPS between parents and children. It may provide valuable insights into prevention and management strategies for patients presenting with MUPS, which could improve health outcomes, quality of life, and, ultimately, reduce healthcare costs. The primary objective of this systematic review was to identify and summarise the results of observational studies, based in primary care or community settings, examining the association of GP consultations for MUPS between parents and children.

\section{METHOD}

Figure 1. Process of systematic search and selection of studies.

\section{Search strategy}

MEDLINE ${ }^{\circledR}$, Embase, CINAHL, and

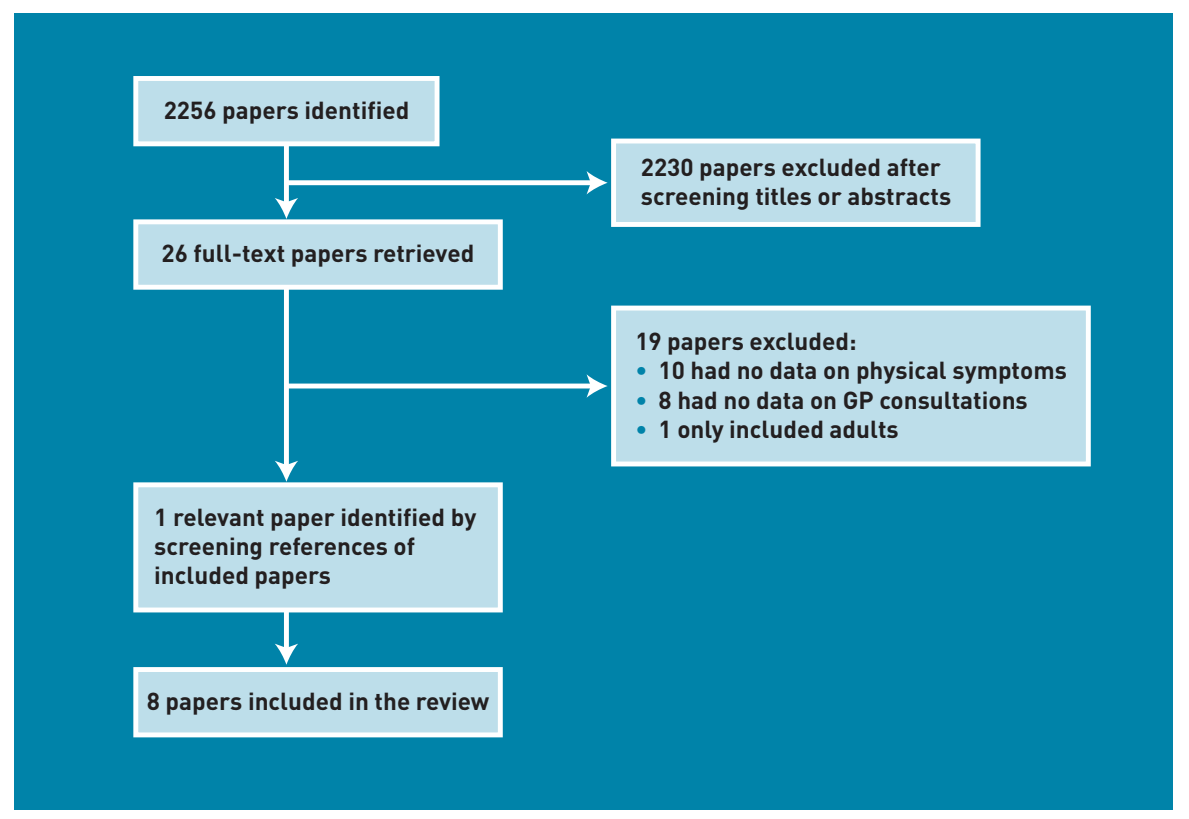

PsycINFO bibliographic databases were searched from their inception to October 2012. Medical Subject Heading (MeSH) and free-text terms on MUPS and primary care were used to identify papers. (The detailed search strategy is available on request from the authors.) Additionally, the reference lists of relevant papers were examined and their citations traced using the Social Science Citation Index. No restrictions were imposed on the language of publication. Local experts were contacted to identify additional relevant studies.

\section{Study selection}

The selection included primary care and population-based observational studies that investigated the association between GP consultations for MUPS, medical diagnosis of functional somatic syndromes, or history of treated MUPS in parents and GP consultations for MUPS in children aged 1 to 17 years. It included studies in which GP consultation data for MUPS were obtained using primary care medical records, self-reported data, or both data sources. Only studies in which physical symptoms were operationally defined as MUPS or specifically referred to as functional, somatic, or non-specific were included. Studies were included regardless of the time period over which these associations had occurred.

The titles and abstracts of all studies were screened and irrelevant studies were excluded. Two reviewers assessed full-text papers to determine the eligibility of studies that appeared to meet the inclusion criteria, or when a defined decision could not be made based on the title and/or abstract alone. Any disagreements were resolved by consensus, or reconciled by a third reviewer

\section{Data extraction and quality assessment}

Standardised forms were used for methodological quality assessment and data extraction. The following information was extracted: study setting, design, population, number of participants and their demographic characteristics, type of MUPS, data-collection methods, and outcomes of association of GP consultations for MUPS between parents and children.

The association of GP consultations for MUPS between parents and children was defined and measured as the association between GP consultations for MUPS, history of treated MUPS, or medical diagnosis of functional somatic syndromes in parents and GP consultations for MUPS in children. The methodological quality of included 
Table 1. Quality assessment of included studies

\begin{tabular}{|c|c|c|c|c|c|c|c|c|c|c|c|c|c|c|c|}
\hline \multirow[b]{2}{*}{ Study } & \multicolumn{15}{|c|}{ Quality-assessment items ${ }^{a}$} \\
\hline & A & B & C & D & $\mathbf{E}$ & $\mathbf{F}$ & G & H & I & J & $\mathrm{K}$ & $\mathbf{L}$ & M & $\mathbf{N}$ & $\begin{array}{l}\text { Overall } \\
0 \text { quality }\end{array}$ \\
\hline Balague et al, $1995^{27}$ & + & + & + & + & - & + & + & + & + & + & na & na & + & + & + High \\
\hline Balague et al, $1994^{29}$ & + & + & + & + & - & + & + & + & na & + & na & na & + & + & + High \\
\hline Campo et al, $2007^{34}$ & + & + & + & + & - & + & + & + & + & na & na & na & + & + & + High \\
\hline Cardol et al, $2006^{35}$ & + & + & + & + & + & + & + & + & + & na & na & na & + & + & + High \\
\hline Craig et al, $2002^{24}$ & + & + & + & + & - & + & + & + & na & + & na & na & + & + & + High \\
\hline Levy et al, $2004^{23}$ & + & + & + & + & - & + & + & + & + & - & na & na & + & + & + High \\
\hline Levy et al, 200036 & + & + & + & + & - & + & + & + & + & na & na & na & + & + & + High \\
\hline Little et al, $2001^{22}$ & + & + & + & + & + & + & + & + & + & + & na & + & + & + & + High \\
\hline
\end{tabular}

studies was appraised using a methodological quality-assessment checklist for observational studies. ${ }^{33}$ This checklist consists of 15 items covering internal and external validity (see Appendix 1). The methodological quality for each paper was assessed independently by two reviewers. Each study was scored according to its methodological quality, using the 15-item checklist. Each item was scored positive (+) if it was satisfactorily presented, negative (-) if absent, or (na) if it was not applicable. Some items were not applicable, because of study design Ino losses or dropouts in cross-sectional studies and medical record reviews). The overall methodological quality of each study was rated as 'high' if all or most of the items were fulfilled, 'moderate' if some of the items were fulfilled, and 'low' if few or no items were fulfilled.

\section{RESULTS}

\section{Studies identified}

A total of 2256 papers were identified (1106 MEDLINE, 745 Embase, 113 CINAHL, and 292 PsyclNFO). Of those papers, only eight were included in the review (Figure 1).

\section{Quality assessment}

The overall methodological qualities of included studies were high. The following items were attained by all studies: clearly defined objective, appropriate study design, representative sample, appropriate selection of outcome, appropriate measurement of outcome, standardised data collection, appropriate analysis of outcomes, and numerical description of important outcomes (Table 1).

\section{Characteristics of included studies}

Study characteristics are presented in Table 2. Included studies were published in English and were conducted in four different countries. Six studies were conducted in primary care and two studies identified children from schools. There

\section{Table 2. Characteristics of included studies}

\begin{tabular}{|c|c|c|c|c|c|c|c|c|}
\hline Study & Country & Setting & Design & $\begin{array}{l}\text { Children's } \\
\text { age, years }\end{array}$ & $\begin{array}{l}\text { Sex, } \\
\% \text { females }\end{array}$ & $\begin{array}{l}\text { Sample } \\
\text { size }\end{array}$ & $\begin{array}{l}\text { Physical } \\
\text { symptoms }\end{array}$ & Data source \\
\hline Balague et al, $1995^{27}$ & Switzerland & School & Cross-sectional & l $12-17$ & 52.5 & 615 & NLBP & $\begin{array}{l}\text { History of NLBP in parent and children } \\
\text { was reported by children }\end{array}$ \\
\hline Balague et al, 1994 ${ }^{29}$ & Switzerland & School & Cross-sectional & $8-16$ & 50.6 & 1716 & NLBP & $\begin{array}{l}\text { History for NLBP in parent and children was } \\
\text { reported by children aged } 13-16 \text { years, and } \\
\text { by parents for younger children }\end{array}$ \\
\hline Campo et al, $2007^{34}$ & US & $\begin{array}{l}\text { Primary } \\
\text { care }\end{array}$ & Case-control & $8-15$ & 48.5 & 135 & FAP & $\begin{array}{l}\text { History of MUPS in mothers and FAP in } \\
\text { children was reported by mothers }\end{array}$ \\
\hline Cardol et al, 2006 35 & $\begin{array}{l}\text { The } \\
\text { Netherlands }\end{array}$ & $\begin{array}{l}\text { Primary } \\
\text { care }\end{array}$ & $\begin{array}{l}\text { Retrospective } \\
\text { cohort }\end{array}$ & $1-12$ & 60 & 65671 & MUPS & Medical records review for parents and children \\
\hline Craig et al, $2002^{24}$ & UK & $\begin{array}{l}\text { Primary } \\
\text { care }\end{array}$ & Cross-sectional & $4-8$ & 52 & 151 & MUPS & $\begin{array}{l}\text { Medical records review for mothers; } \\
\text { mothers reported on MUPS and GP } \\
\text { consultations in children }\end{array}$ \\
\hline Levy et al, 2004²3 & US & $\begin{array}{l}\text { Primary } \\
\text { care }\end{array}$ & Case-control & $8-15$ & 51 & 641 & MUPS & $\begin{array}{l}\text { Medical records review for maternal IBS } \\
\text { and FAP and for MUPS in the child, plus } \\
\text { self-report data on MUPS in the child by mother }\end{array}$ \\
\hline Levy et al, $2000^{36}$ & US & $\begin{array}{l}\text { Primary } \\
\text { care }\end{array}$ & Case-control & $3-14$ & 49 & 1277 & Gl symptoms & Medical records review for parents and children \\
\hline Little et al, $2001^{22}$ & UK & $\begin{array}{l}\text { Primary } \\
\text { care }\end{array}$ & Cross-sectional & $<16$ & 50 & 456 & MUPS & $\begin{array}{l}\text { History of GP consultations for MUPS in } \\
\text { parents and children was reported by parents }\end{array}$ \\
\hline
\end{tabular}

$F A P=$ functional abdominal pain. $G I=$ gastrointestinal. IBS = irritable bowel syndrome. MUPS = medically unexplained physical symptoms. NLBP = non-specific low back pain. 
were four cross-sectional surveys, three case-control studies, and one retrospective cohort study. In four studies, the parent or the child reported information on MUPS and GP consultations, and the remaining studies used either medical records alone or medical records combined with selfreported data. The mean age of children ranged between 8.5 and 14 years. The mean proportion of females was $52 \%$ (range $49 \%$ to $60 \%$ ).

\section{Association of GP consultations for MUPS between parents and children}

Table 3 presents the associations of GP consultations for MUPS between parents and children. Six studies found significant associations between GP consultations for MUPS, history of treated NLBP or IBS in parents, and GP consultations for MUPS in children (Table 3).22-24,27,29,34-36 Four studies reported the strength of associations as adjusted odds ratios (ORs) with 95\% confidence intervals (Cls), and two studies used adjusted $P$-values. Two studies did not report the strength of association, but stated that it was not significant.

One study ( $n=456$ ) found a significant association between self-reported GP consultations for MUPS in parents and children (OR $=1.36,95 \% \mathrm{Cl}=1.10$ to 1.70$).{ }^{22}$ Another study ( $n=151$ ) showed a significant association between somatisation disorder in mothers and maternal reports of GP consultations for MUPS in children ladjusted $P<0.001$ ). ${ }^{24}$ Three studies looked at IBS; one reported significant associations between IBS in parents and recorded GP consultations for $\mathrm{Gl}$ symptoms in 1277 children $(\mathrm{OR}=2.2,95 \% \mathrm{Cl}=1.62$ to 2.98$)$, 36 and another between IBS in mothers and recorded GP consultations for $\mathrm{Gl}$ and nonGI symptoms in 641 children $^{23}$ ladjusted $P=0.006$ and 0.001 , respectively). One study ( $n=135$ ) showed no significant association between history of IBS, migraine, and somatoform disorder in mothers and maternal reports of GP consultations for FAP in children IOR was reported as not significant). ${ }^{34}$ Two studies investigated the association of reported history of treated NLBP in parents and history of NLBP in children; one study $(n=1716)$ showed a significant association $(0 R=2.10,95 \%$ $\mathrm{Cl}=1.56$ to 2.83$),{ }^{29}$ whereas the other study ( $n=615)$ found no significant association (OR was reported as not significant). ${ }^{27}$ The final study ( $n=65671)$ reported the percentage of variance in similarity of recorded GP consultations among family members explained by family influence. ${ }^{35}$ For example, the variation in GP consultations by mothers and daughters that could be explained by family influence was $48.4 \%$ for headache and $34.7 \%$ for abdominal pain (Table 3).

Owing to the high degree of study heterogeneity between studies, pooled estimates of the strength of associations were not performed.

\section{DISCUSSION}

\section{Summary}

This review provides evidence that GP consultations for MUPS in parents are associated with GP consultations for MUPS in children. The review included eight papers, of which six found significant associations between GP consultations for MUPS in parents and children. Differences between studies in study designs, settings, data-collection methods, ages and numbers of included children, and types of included MUPS may partly explain the lack of association found in two studies. For example, these two studies examined the association between the lifetime prevalence of reported NLBP in children and history of treated NLBP in parents, and reported mixed findings. In the first study, ${ }^{29}$ schoolchildren reported information on their lifetime prevalence of NLBP as well as the history of treated NLBP in parents, whereas in the other study, ${ }_{1}^{27}$ both parents and children reported information on the history of their NLBP. Therefore, a possible lack of children's knowledge of their parents' history of treated NLBP, or recall bias, may partially explain the contradictory findings of these two studies.

The mechanisms underlying the association of GP consultations for MUPS between parents and children are not fully clear. However, there is some evidence that genetic effects, 37,38 shared environmental factors, 39,40 and childhood social learning of illness behaviour 24,36,41,42 may explain this association. Although the majority of studies controlled for some possible confounding factors, it has been suggested that a parental decision to seek health care for their children may reflect parental health attitudes, health beliefs, and consulting behaviour, rather than the child healthcare needs. ${ }^{23,34,36}$ Therefore, the association of GP consultations for MUPS in parents and children may be explained by biased parental perception of symptoms in children or parental concentration on the symptoms they have themselves. For example, in one study, children with GI symptoms were interviewed independently of their mothers with IBS, and it was found that the difference between children of 


\section{Table 3. Associations of GP consultations for MUPS between parents and their children}

\begin{tabular}{|c|c|c|c|}
\hline Study & MUPS & Time period & Summary of association \\
\hline Balague et al, $1995^{27}$ & $\begin{array}{l}\text { NLBP in children } \\
\text { and parents }\end{array}$ & Lifetime & $\begin{array}{l}\text { No significant association was found } \\
\text { between parental reported history of } \\
\text { treated NLBP and children's lifetime } \\
\text { history of NLBP }\end{array}$ \\
\hline Balague et al, $1994^{29}$ & $\begin{array}{l}\text { NLBP in children } \\
\text { and parents }\end{array}$ & Lifetime & $\begin{array}{l}\text { Children of parents who had been } \\
\text { treated for NLBP were more likely to } \\
\text { report a history of NLBP themselves }\end{array}$ \\
\hline Campo et al, 200734 & $\begin{array}{l}\text { Children consulting } \\
\text { with FAP and } \\
\text { maternal MUPS }\end{array}$ & Lifetime & $\begin{array}{l}\text { No significant association was found } \\
\text { between child GP consultations for } \\
\text { FAP and maternal MUPS }\end{array}$ \\
\hline Cardol et al, 2006 35 & $\begin{array}{l}\text { MUPS in children } \\
\text { and parents }\end{array}$ & 1 year & $\begin{array}{l}\text { There was an association in GP } \\
\text { consultation frequency for headache } \\
\text { and abdominal pain between children } \\
\text { and their parents compared to other } \\
\text { families in which children consulted } \\
\text { for physical trauma or chronic disease; } \\
\text { association was reported as percentage } \\
\text { of shared variance in consultation } \\
\text { frequency between families }\end{array}$ \\
\hline
\end{tabular}

Factors adjusted for in

multivariable analyses Strength of association

Child sex, age, walk time, sports Crude $\mathrm{OR}=1.09,95 \% \mathrm{Cl}$ was not

activity, negative affect, positive reported; adjusted OR was not

affect, siblings' LBP reported

\begin{tabular}{|c|c|}
\hline $\begin{array}{l}\text { Child age, sex, competitive } \\
\text { sports activity, TV watched } \\
\text { (hours/week) }\end{array}$ & $\begin{array}{l}\text { Crude } \mathrm{OR}=1.87,95 \% \mathrm{Cl}=1.42 \\
\text { to } 2.48 \text {; adjusted } \mathrm{OR}=2.10,95 \% \\
\mathrm{Cl}=1.56 \text { to } 2.83\end{array}$ \\
\hline $\begin{array}{l}\text { Maternal age, maternal } \\
\text { psychiatric (anxiety and } \\
\text { depressive) disorders, } \\
\text { and family intact (child } \\
\text { lives with biological parents) }\end{array}$ & $\begin{array}{l}\text { For IBS: crude } \mathrm{OR}=3.9,95 \% \\
\mathrm{Cl}=1.5 \text { to } 10.3 ; \text { adjusted } \mathrm{OR}=1.8, \\
95 \% \mathrm{Cl}=0.6 \text { to } 6.1 ; \text { for migraine: } \\
\text { crude } \mathrm{OR}=2.4,95 \% \mathrm{Cl}=1.1 \text { to } 5.3 \text {, } \\
\text { adjusted } \mathrm{OR}=1.4,95 \% \mathrm{Cl}=0.6 \text { to } 3.7\end{array}$ \\
\hline $\begin{array}{l}\text { Child age and sex and } \\
\text { GP practice }\end{array}$ & $\begin{array}{l}\text { Percentage of variation in } \\
\text { consultation frequency } \\
\text { attributed to shared family } \\
\text { factors }(95 \% \mathrm{Cl}) \text { : }\end{array}$ \\
\hline
\end{tabular}

fequency between families

\begin{tabular}{|c|c|c|c|}
\hline $\begin{array}{c}\text { Family } \\
\text { members }\end{array}$ & & $\begin{array}{l}\text { Abdominal } \\
\text { pain }\end{array}$ & $\begin{array}{l}\text { Minor } \\
\text { ailments }\end{array}$ \\
\hline $\begin{array}{c}\text { Mother/ } \\
\text { son }\end{array}$ & $\begin{array}{c}20.2 \\
(16.4 \\
\text { to } 24.1)\end{array}$ & $\begin{array}{c}34.1 \\
(31.0 \\
\text { to } 37.1)\end{array}$ & $\begin{array}{c}19 \\
(18.0 \text { to } \\
20.0)\end{array}$ \\
\hline $\begin{array}{l}\text { Mother/ } \\
\text { daughter }\end{array}$ & $\begin{array}{c}48.4 \\
(44.5 \text { to } \\
2.3)\end{array}$ & $\begin{array}{c}34.7 \\
(31.7 \text { to } \\
37.7)\end{array}$ & $\begin{array}{c}23.2 \\
\text { (22.1 to } \\
24.3)\end{array}$ \\
\hline $\begin{array}{c}\text { Father/ } \\
\text { son }\end{array}$ & $\begin{array}{c}4.7 \\
(2.7 \text { to } \\
7.2)\end{array}$ & $\begin{array}{c}17.1 \\
14.4 \text { to } \\
(19.8)\end{array}$ & $\begin{array}{c}8.8 \\
(8.0 \text { to } \\
9.7)\end{array}$ \\
\hline $\begin{array}{l}\text { Father/ } \\
\text { daughter }\end{array}$ & $\begin{array}{c}14.4 \\
(11.1 \text { to } \\
18.1)\end{array}$ & $\begin{array}{c}6.9 \\
(5.1 \text { to } \\
8.9]\end{array}$ & $\begin{array}{c}4.9 \\
(4.3 \text { to } \\
5.6)\end{array}$ \\
\hline
\end{tabular}

\begin{tabular}{|c|c|c|c|c|c|}
\hline Craig et al, $2002^{24}$ & $\begin{array}{l}\text { MUPS in children } \\
\text { and mothers }\end{array}$ & 3 months & $\begin{array}{l}\text { Children of somatising mothers had } \\
\text { significantly more GP consultations } \\
\text { for MUPS compared to children of } \\
\text { control mothers }\end{array}$ & $\begin{array}{l}\text { Child age and sex, child } \\
\text { emotional or behavioural } \\
\text { problems, mother's exposure } \\
\text { to adversity in her own } \\
\text { childhood, and maternal } \\
\text { psychiatric disorders }\end{array}$ & Adjusted $P<0.001$ \\
\hline Levy et al, 2004²3 & $\begin{array}{l}\text { GI and non-GI } \\
\text { symptoms in } \\
\text { children and } \\
\text { maternal IBS } \\
\text { diagnosis }\end{array}$ & 3 years & $\begin{array}{l}\text { Children of mothers with IBS had } \\
\text { significantly more GP consultations } \\
\text { for GI and non-GI symptoms than } \\
\text { controls }\end{array}$ & $\begin{array}{l}\text { Child age and sex, child } \\
\text { sense of competence, child } \\
\text { coping style, child } \\
\text { psychological symptoms, } \\
\text { and maternal stress, and } \\
\text { psychological symptoms }\end{array}$ & $\begin{array}{l}\text { For GI symptoms, crude } P=0.005 \\
\text { and adjusted } P=0.006 \text {; for non-GI } \\
\text { symptoms, crude and adjusted } \\
P=0.001\end{array}$ \\
\hline Levy et al, 200036 & $\begin{array}{l}\text { Children's GI } \\
\text { symptoms and } \\
\text { parental IBS } \\
\text { diagnosis }\end{array}$ & 1 year & $\begin{array}{l}\text { Children of parents with IBS had } \\
\text { significantly more GP consultations for } \\
\text { GI symptoms compared to control } \\
\text { children and parents }\end{array}$ & $\begin{array}{l}\text { Child age and sex, parent age } \\
\text { and sex, parental healthcare } \\
\text { use for non-GI disorders }\end{array}$ & $\begin{array}{l}\text { Crude OR not reported, adjusted } \\
\mathrm{OR}=2.2,95 \% \mathrm{Cl}=1.62 \text { to } 2.98\end{array}$ \\
\hline Little et al, $2001^{22}$ & $\begin{array}{l}\text { MUPS in children } \\
\text { and parents }\end{array}$ & 1 year & $\begin{array}{l}\text { GP consultations for MUPS in high- } \\
\text { attending children were significantly } \\
\text { associated with parental GP } \\
\text { consultations for MUPS }\end{array}$ & $\begin{array}{l}\text { Child sex; parental perceived } \\
\text { health of the child, willingness } \\
\text { to tolerate child symptoms, } \\
\text { health anxiety, and council } \\
\text { house tenancy }\end{array}$ & $\begin{array}{l}\text { Crude OR not reported, adjusted } \\
\mathrm{OR}=1.36,95 \% \mathrm{Cl}=1.10 \text { to } 1.70\end{array}$ \\
\hline
\end{tabular}

$F A P=$ functional abdominal pain. $G I=$ gastrointestinal. IBS = irritable bowel syndrome. $L B P=$ lower back pain. MUPS = medically unexplained physical symptoms.

$N L B P=$ non-specific low back pain. $O R=$ odds ratio . 
cases and controls was greater when the mothers reported on symptoms in children compared to children's reports on their own symptoms. ${ }^{23}$ Also, the observed association of GP consultations for MUPS between parents and children may perhaps just reflect patterns of GP consultations more generally.

\section{Strengths and limitations}

This review included only eight studies. This was despite a comprehensive search covering several electronic bibliographic databases. The citations of all included studies were searched, and no further relevant studies were identified. One relevant paper was identified through searching the references lists of included studies. The search did not address all sources of grey literature. However, local experts were contacted to identify any relevant studies, and the search was not restricted to English language publications. No studies were excluded from the review on the basis of quality assessment.

In addition to the high degree of heterogeneity among included studies, there are some limitations that should be considered when interpreting the results of this review. First, the majority of included studies relied on selfreported data, which are prone to recall bias. However, two studies examined agreement between self-reported and documented consultation for MUPS, and they showed good agreement.22,24 Second, four studies used self-reported data on the history of IBS or treated MUPS rather than patterns of GP consultations for these conditions. However, it is reasonable to suggest that those parents had to consult a medical practitioner to receive treatment and diagnosis for those conditions. Third, owing to the small number of included studies, publication bias was not assessed. Therefore, the potential for publication bias remains. Fourth, although all studies were generally of high methodological quality, only two reported a priori calculation of sample size. Finally, four studies were cross-sectional and were therefore unable to distinguish the direction of associations.

\section{Comparison with existing literature}

This is the first systematic review to summarise the research evidence on the association of GP consultations for MUPS between parents and children. in agreement with findings of other studies that specifically focused on the association of self-reported MUPS (without including GP consultations data) between parents and children, which showed mixed results. $25,26,28,31,32,43$ For example, two studies reported significant associations for self-reported history of FAP between parents and children, ${ }^{31,32}$ whereas this association was found to be non significant in another study. ${ }^{26}$

\section{Implications for practice}

The potential impact of parental GP consultations for MUPS on the health and GP consultations of their children has implications for primary care. It is important that GPs be aware of this link, as such insights may direct the GP toward alternative management approaches. For example, cognitive behavioural therapy (CBT) targeting children's coping responses to FAP and parents' responses to pain in their children was associated with significant reduction in pain and MUPS severity in children in the CBT group compared to a control group. ${ }^{44}$ Another study showed that CBT for children with persistent MUPS and anxiety was associated with significant improvements in anxiety symptoms and reduction in pain severity and discomfort due to $\mathrm{Gl}$ symptoms, as compared to controls. ${ }^{45}$

This review provides some evidence of an association between GP consultations for MUPS in parents and children. There are a limited number of studies that have investigated the association of GP consultations for MUPS between parents and children. Further longitudinal research, without relying on retrospective recall of physical symptom experience, is needed to further investigate the association between GP consultations for MUPS among parents and children. Future studies may wish to investigate this association by focusing on the whole spectrum of MUPS, including different age groups of children. Such research may provide more precise measures of the impact of parental MUPS on the health and GP consultations of their children, which has implications for the management and prevention of physical symptoms.

\section{Discuss this article}

Contribute and read comments about this article on the Discussion Forum: http://www.rcgp.org.uk/bjgp-discuss
The findings from this review are 


\section{REFERENCES}

1. Jordan KP, Kadam UT, Hayward R, et al. Annual consultation prevalence of regional musculoskeletal problems in primary care: an observational study. BMC Musculoskelet Disord 2010; 11: 144

2. Latinovic R, Gulliford M, Ridsdale L. Headache and migraine in primary care: Consultation, prescription, and referral rates in a large population. J Neurol Neurosurg Psychiatry 2006; 77(3): 385-387.

3. Nimnuan C, Hotopf M, Wessely S. Medically unexplained symptoms: An epidemiological study in seven specialities. J Psychosom Res 2001; 51(1) 361-367.

4. Melville DI. Descriptive clinical research and medically unexplained physical symptoms. J Psychosom Res 1987; 31(3): 359-365

5. Kroenke K, Jackson JL. Outcome in general medical patients presenting with common symptoms: a prospective study with a 2-week and a 3-month followup. Fam Pract 1998; 15(5): 398-403.

6. Jackson JL, Passamonti ML. Symptoms in primary care: outcomes at five years $J$ Gen Intern Med 2001; 16(1 suppl): 142

7. El-Metwally A, Salminen JJ, Auvinen A, et al. Prognosis of non-specific musculoskeletal pain in preadolescents: a prospective 4-year follow-up study til adolescence. Pain 2004; 110(3): 550-559.

8. Perquin CW, Hunfeld JA, Hazebroek-Kampschreur AA, et al. The natural course of chronic benign pain in childhood and adolescence: a two-year populationbased follow-up study. Eur J Pain 2003; 7(6): 551-559.

9. Hotopf M, Carr S, Mayou R, et al. Why do children have chronic abdominal pain, and what happens to them when they grow up? Population based cohort study. BMJ 1998; 316(7139): 1196-1200.

10. Gold JI, Mahrer NE, Yee J, Palermo TM. Pain, fatigue, and health-related quality of life in children and adolescents with chronic pain. Clin J Pain 2009; 25(5): 407-412.

11. Roth-Isigkeit $\mathrm{A}$, Thyen $\mathrm{U}$, Stoven $\mathrm{H}$, et al. Pain among children and adolescents: restrictions in daily living and triggering factors. Pediatrics 2005; 115(2): e152162

12. Hunfeld JA, Perquin CW, Hazebroek-Kampschreur AA, et al. Physically unexplained chronic pain and its impact on children and their families: the mother's perception. Psychol Psychother 2002; 75(Pt 3): 251-260.

13. Mallen CD, Mottram S, Thomas E. Is childhood pain associated with future mental health problems? A population based study of young adults in North Staffordshire. Soc Psychiatry Psychiatr Epidemiol 2009; 44(6): 489-494.

14. Campo JV. Functional abdominal pain in childhood: lifetime and familial associations with irritable bowel syndrome and psychiatric disorders. Prim Psychiatry 2007; 14(4): 64-68.

15. Berntsson LT, Gustafsson JE. Determinants of psychosomatic complaints in Swedish schoolchildren aged seven to twelve years. Scand J Public Health 2000 28(4): 283-293.

16. Eminson M, Benjamin S, Shortall A, et al. Physical symptoms and illness attitudes in adolescents: an epidemiological study. J Child Psychol Psychiatry 1996; 37(5): 519-528

17. Saps M, Seshadri R, Sztainberg M, et al. A prospective school-based study of abdominal pain and other common somatic complaints in children. J Pediatr 2009; 154(3): 322-326.

18. Egger HL, Costello EJ, Erkanli A, Angold A. Somatic complaints and psychopathology in children and adolescents: stomach aches, musculoskeletal pains, and headaches. J Am Acad Child Adolesc Psychiatry 1999; 38(7): 852-860.

19. Fiddler M, Jackson J, Kapur N, et al. Childhood adversity and frequent medical consultations. Gen Hosp Psychiatry 2004; 26(5): 367-377.

20. Goodwin RD, Hoven CW, Murison R, Hotopf M. Association between childhood physical abuse and gastrointestinal disorders and migraine in adulthood. $\mathrm{Am} \mathrm{J}$ Public Health 2003; 93(7): 1065-1067.

21. Virtanen R, Aromaa M, Koskenvuo M, et al. Prevalence and incidence of headache in adolescent finnish twins. Headache 2009; 49(10): 1503-1512.

22. Little P, Somerville J, Williamson I, et al. Family influences in a cross-sectional survey of higher child attendance. Br J Gen Pract 2001; 51(473): 977-981, 984.

23. Levy RL, Whitehead WE, Walker LS, et al. Increased somatic complaints and health-care utilization in children: effects of parent IBS status and parent response to gastrointestinal symptoms. Am J Gastroenterol 2004; 99(12): 2442-2451

24. Craig TKJ, Cox AD, Klein K. Intergenerational transmission of somatization behaviour: a study of chronic somatizers and their children. Psychol Med 2002; 32(5): 805-816.

25. Jones GT, Silman AJ, Macfarlane GJ. Parental pain is not associated with pain in the child: a population based study. Ann Rheum Dis 2004; 63(9): 1152-1154.

26. Huang RC, Palmer LJ, Forbes DA. Prevalence and pattern of childhood abdominal pain in an Australian general practice. J Paediatr Child Health 2000; 36(4): 349-353.

27. Balague F, Skovron ML, Nordin M, et al. Low back pain in schoolchildren. A study of familial and psychological factors. Spine (Phila Pa 1976) 1995; 20(11): 1265-1270

28. Saunders K, Korff MV, Leresche L, Mancl L. Relationship of common pain conditions in mothers and children. Clin J Pain 2007; 23(3): 204-213.

29. Balague F, Nordin M, Skovron ML, et al. Non-specific low-back pain among schoolchildren: a field survey with analysis of some associated factors. J Spinal Disord 1994; 7(5): 374-379.

30. Salminen JJ. The adolescent back. A field survey of 370 Finnish schoolchildren Acta Paediatr Scand Suppl 1984; 315: 1-122.

31. Devanarayana NM, de Silva DGH, de Silva HJ. Recurrent abdominal pain syndrome in a cohort of Sri Lankan children and adolescents. J Trop Pediatr 2008; 54(3): 178-183.

32. Boey CC, Goh KL. Predictors of recurrent abdominal pain among 9 to 15 -yearold urban school-children in Malaysia. Acta Paediatr 2001; 90(3): 353-355.

33. Mallen CD, Peat $\mathrm{G}$, Thomas $\mathrm{E}$, et al. Prognostic factors for musculoskeletal pain in primary care: a systematic review. Br J Gen Pract 2007; 57(541): 655-661.

34. Campo JV, Bridge J, Lucas A, et al. Physical and emotional health of mothers of youth with functional abdominal pain. Arch Pediatr Adolesc Med 2007; 161(2): 131-137.

35. Cardol M, van den Bosch WJ, Spreeuwenberg P, et al. All in the family: headaches and abdominal pain as indicators for consultation patterns in families. Ann Fam Med 2006; 4(6): 506-511.

36. Levy RL, Whitehead WE, Von Korff MR, Feld AD. Intergenerational transmission of gastrointestinal illness behavior. Am J Gastroenterol 2000; 95(2): 451-456.

37. Larsson B, Bille B, Pedersen NL. Genetic influence in headaches: a Swedish twin study. Headache 1995; 35(9): 513-519.

38. Morris-Yates A, Talley NJ, Boyce PM, et al. Evidence of a genetic contribution to functional bowel disorder. Am J Gastroenterol 1998; 93(8): 1311-1317.

39. Huurre T, Junkkari H, Aro H. Long-term psychosocial effects of parental divorce: a follow-up study from adolescence to adulthood. Eur Arch Psychiatry Clin Neurosci 2006; 256(4): 256-263.

40. Troxel WM, Matthews KA. What are the costs of marital conflict and dissolution to children's physical health? Clin Child Fam Psychol Rev 2004; 7(1): 29-57.

41. Levy RL, Langer SL, Whitehead WE. Social learning contributions to the etiology and treatment of functional abdominal pain and inflammatory bowel disease in children and adults. World J Gastroenterol 2007; 13(17): 2397-2403.

42. Cardol M, van Dijk L, van den Bosch WJ, et al. Striking variations in consultation rates with general practice reveal family influence. BMC Fam Pract 2007; 8: 4.

43. Kashikar-Zuck S, Lynch AM, Slater S, et al. Family factors, emotional functioning, and functional impairment in juvenile fibromyalgia syndrome. Arthritis Rheum 2008; 59(10): 1392-1398.

44. Levy RL, Langer SL, Walker LS, et al. Cognitive-behavioral therapy for children with functional abdominal pain and their parents decreases pain and other symptoms. Am J Gastroenterol 2010; 105(4): 946-956.

45. Warner CM, Colognori D, Kim RE, et al. Cognitive-behavioral treatment of persistent functional somatic complaints and pediatric anxiety: an initial controlled trial. Depress Anxiety 2011; 28(7): 551-559. 


\section{Appendix 1. Items used to assess the quality of observational studies}

A Clearly defined study objective

Appropriate design for study question

Inclusion and exclusion criteria clear and appropriate

Representative sample (and comparison)

Sample size calculation presented

Appropriate selection of outcome

Appropriate measurement of outcome

Standardised collection of data

Adequate length of follow-up for research question

Baseline participation $>70 \%$ (all groups)

Losses and dropouts $<20 \%$

Adequate description of losses and completers

Appropriate analysis of outcomes measured

Numerical description of important outcomes given

Adjusted and unadjusted calculations provided (with confidence interval if appropriate) 